\title{
Konsep Memaafkan dalam Psikologi Positif
}

\author{
Ulin Nihayah $^{1}$, Salsabila Ade Putri ${ }^{2}$, Rahmat Hidayat ${ }^{3}$ \\ 1,2,3 UIN Walisongo Semarang \\ *Corresponding author, e-mail: Rahmat 1901016041@student.walisongo.ac.id
}

\begin{abstract}
Forgiveness is a very important positive force that exists within a person so as not to always be trapped in a negative emotional state which can proceed to release all negative emotions such as feelings of anger, feelings of hatred, burt and even the desire to take revenge for others. how others treat us. Forgiveness is also included in a concept contained in the study of positive psychology which according to Martin Seligman that positive psychology does not only focus on a person's weakness or mental illness but also focuses on the positive strengths possessed by each person to regulate these negative emotions into a positive emotion. One way to develop yourself is by forgiving. Forgiveness has a very important role in a person's mental health, where when an individual is having feelings of anger, burt, disappointment, and feelings of hatred towards others, this can increase the negative emotions that exist within the individual which can later cause stress. frustration, sadness and even the desire to take revenge against someone because they have harbored these negative emotions for too long which are eventually released with revenge. Forgiveness is very important because forgiving is a way to release all negative emotions that exist in a person and when successfully released it will have positive impacts that can be felt by the person, especially the positive impact on his mental health, which forgiveness will create feelings a person becomes more relieved, feels better, and the mood becomes calmer and more comfortable, therefore forgiveness is very important to do. The purpose of thr journal writing is, 1) to understand the concept of forgiveness within positive psychology, 2) understanding the relationship between forgivrness and mental health, 3) understanding the importance of forgiveness toward mental health.Descriptive qualitative writing method used in this study is to describe several important concepts that will be discussed so that they are clearer and easier to understand. The results of the study show that people who always forgive will make themselves calmer and make the quality of their lives better because basically forgiveness has a very clear urgency, especially in a person's mental health condition.
\end{abstract}

Keyword: Forgiveness, Psychology Positive, Mental Healtby

\section{Pendahuluan}

Manusia tidak dapat hidup sendiri, itu yang mengharuskan setiap manusia untuk bisa saling berhubngan dengan orang-orang disekitarnya, dan dalam hubungan antar manusia tidak lah sempurna, pasti setiap manusia pernah melakukan kesalahan dan pasti setiap manusia atau individu pasti pernah merasa sakit hati, marah, kecewa, pada orang lain karena kesalahn yangdibuat oleh orang tersebut. Sejatinya rasa marah, kecewa dan sakit hati tersebut wajar jika ada seseorang melakukan kesalahan apalagi jika kesalahan tersebut sangat fatal. Terkadang karena kesalahan fatal tersebut membuat kita selalu memikirkannya, dan di saat kita memikirkan atau mengingat kesalahan tersebut membuat kita menjadi sedih, marah, kecewa, sakit hati, dan pada saat itu pula semua emosi negatif akan terpendam juga di dalam hati dan menciptakan perasaan kebencian, jika semakin lama memendam perasaan kebencian tersebut tidak menutup kemungkinan jika individu akan menaruh atau menumbuhkan rasa keinginan untuk balas dendam terhadap sang pelaku. Dan hal tersbut sangat tidak baik untuk kesehatan mental seseorang. Sesorang yang menyimpan terlalu lama perasaan marah dan benci akan membuat orang tersebut 
akan selalu mengingat apa kesalahan yang orang lain perbuat pada dirinya, dan pada saat mengingat hal tersebut makan akan terbuka kembali luka tersebut, membuatnya semakin merasa sedih, terpuruk, marah, stress, frustasi bahkan ada yang memiliki obsesi untuk membalas dendam.

Begitu banyak dampak negatif yang diperoleh seseorang dengan memendam emosi negative, seperti perasaan marah, benci, kecewa terutama bagi keshatan mental seseorang. Emosi negative yang terlalu lama tersimpan akan menimbulkan stress pada orang tersebut bahkan justru akan memebuat sakit hati yang makin mendalam dan dapat menimbulkan perasaan keinginan untuk balas dendam, baik itu hanya tersimpan ataupaun hingga dilampiaskan, keduanya samasama berdampak negative pada kesehatan mental seseorang. Menyimpan dendam akan menimbulkan banyak dampak negative terutama bagi kesehatan mental individu tersebut. Orang yang menyimpan dendam akan memiliki suatu perasaan atau emosi yang negative, dan ini juga dapat menimbulkan stress yang lebih besar, dan juga dapat menimbulkan frustasi hingga gangguan kecemasan, karena mereka akan selalu mengingat hal-hal yang menyikiti hati orang tersebut. Dan hal ini juga akan memperburuk kondisi fisik orang tersebut. (Detik.com, 2015)

Konsep kajian psikologi positif, sangatlah menarik untuk dibahas terutama yang berhubungan dengan kesehtan mental. Psikologi positif lebih menekankan kepada kekuatan positif yang ada dalam diri manusia. Terlebih lagi dalam psokologi positif ini terdapat konsep memaafkan, dimana konsep itu sangat menarik untuk dikaji, terutama untuk kesehatan mental, terkait dengan perasaan marah, benci, kecewa dan dendam. Karena begitu banyak dampak negative daripada emosi negative tersebut terhadap kesehtam mental seseorang

Memaafkan merupakan pusat untuk mengembangkan manusia yang sehat dan hal yang paling penting adalah pemulihan hubungan interpersonal anatar individu setelah terjadinya konflik. Memaafkan juga dapat mengurangi tanggapan negative yang terjadi setelah konflik. Memang memaafkan bukanlah hal yang mudah, terutama bagi mereka yang sudah telanjur kecewa dengan kesalahan apa yang terjadi di masa lalu, baik. kesalahan yang dibuat oleh diri sendiri maupun orang lain. Individu yang belum bisa memaafkan hal yang menyakitkan yang pernah terjadi tidak menutup kemungkinan individu tersebut akan menyimpan dendam yang berkepanjang, memendam semua rasa sakit hati secara terus menerus akan menimbulkan rasa sakit hati yang makin mendalam, dan berakhir dengan menyimpan dendam.

Memaafkan sangatlah jelas urgensinya dan sangat penting juga untuk dibahas karena memaafkan disini sejalan dengan teori dan konsep dari Nabi SAW yang senang dan suka memaafkan orang lain sekalipun orang yang telah jahat padanya. Nabi sangat sabar ketika menghadapi semuanya dan dengan hal itu maka beliau terlepas dari sifat pendendam. Terdapat ayat Al-Quran yang sejalan dengan teori ini yakni QS Al-Hijr 85 yang berbunyi “Maka maafkanlah mereka dengan cara yang baik" lalu Ali Imran 159 "Maka disebabkan rahmat dari Allab-lab kamu berlaku lemab lembut terbadap mereka. Sekiranya kamu bersikap keras lagi berhati kasar, tentulab mereka menjaubkan diri dari sekelilingmu, karena itu maafkanlah mereka, mohonkanlah ampun bagi mereka dan bermusyawarahlah dengan mereka dalam urusan itu. Kemudian ketika telah membulatkan tekad, maka bertakwalah kepada Allah. Sesunggubnya Allah menyukai orang-orang yang bertawakal kepada-Nya". Jelas sekali termaktub dari ayat-ayat berikut bahwasannya memaafkan itu sangatlah penting bagi seseorang untuk memperbaiki hubungan mereka, memanjangkan umur nya, mempererat tali 
persaudaraannya, dan hingga menjaga kesehatan bagi diri orang-orang yang mampu memaafkan. (Ibrahim, 2020)

Adapun keuntungan lain yang akan didapatkan yakni membersihkan jiwa dan menyucikan hati bagi orang-orang tersebut dan juga merupakan obat dari penyakit dengki dan dendam. Maka Rasul menyarankan untuk tidak saling membenci akan tetapi salinglah mencintai satu sama lain diantara kalian sebagaimana para sahabat dahulu saat jaman Rasulullah SAW. Orang yang meneladani Nabi adalah orang yang mengikuti segala anjurannya dan menjauhi larangannya, sehingga memaafkan lebih baik dan dianjurkan daripada menyimpan dendam yang akan merusak kesehatan seseorang.

Memaafkan memiliki dampak positif yang sangat banyak, terutama bagi ketenangan batin seorang individu, yaitu dengan memaafkan kita dapat merasakan emosi positif karena tidak lagi mengingat hal-hal yang membuat sakit hati, dapat melepaskan perasan-perasaan negative, hati menjadi lebih tenang, dengan berkurangnya rasa marah, tidak lagi merasakan sakit hati dan pastinya dapat menghilangkan rasa dendam yang pernah bersarang dalam hati.(Nasrin, 2018). Ketenangan batin bisa didapatkan oleh seseorang dengan cara berdzikir kepada Allah SWT maka niscaya hati akan menjadi lebih tentram dan nyaman, dzikir itu sendiri jika senantiasa dilakukan oleh seseorang maka akan membuat seseorang akan merasa dekat dengan Allah dan merasa dilindungi dimanapun mereka berada, selain itu dzikir akan dapat memberikan kemuliaan hati bagi orang yang senantiasa melakukannya. Namun sebaliknya jika seseorang sulit dan enggan untuk berdzikir kepada Allah, maka hati seseorang tersebut akan menjadi tertutup dan tentu Allah akan menjauhi orang-orang yang didalam hatinya tidak pernah mengingat-Nya, dan orang-orang yang seperti itu akan sulit mendapatkan ketenangan batin. Ketenangan batin dengan cara berdzikir seharunya sudah menjadi suatu kebutuhan dalam diri manusia, karena banyak manfaat yang akan diperoleh dari dzikir tersebut.(Kallang, 2017).

Berdizkir berdasarkan penjelasan ilmiah itu dapat menenangkan dan menentramkan otak manusia, terlebih jika berdzikir dilakukan oleh seseorang setiap hari dan setiap waktu dalam kondisi apapun dan dimanapun, niscaya orang tersebut setiap hari dalam hidupnya selalu mendapatkan ketenangan batin. Selain itu juga akan mampu menyehatkan dan menetralkan sarafsaraf yang ada pada tubuh manusia, karena pada dasarnya tubuh manusia setiap harinya minta untuk shodakoh, maka shodakoh yang bisa dilakukan bagi tubuh seseorang adalah dengan berdzikir.(Burhanuddin, 2020). Ketenangan batin akan diperoleh dengan mudah bagi orang-orang yang mempunyai ciri seperti hal nya diatas, selalu berdzikir yang akan menjadikan seseorang mendapatkan ketenangan hati, maka dari hal itu memaafkan sudah sangat jelas urgensinya, ketika seseorang sudah mampu memaafkan kesalahan orang lain dengan mudah tanpa adanya rasa dendam yang menyelimuti maka niscaya orang-orang tersebut akan mendapatkan ketenangan hati setelah memaafkan karena sejatinya itulah hikmah dan manfaat dari memaafkan yakni mendapat ketenangan batin dan ketenangan hati.

\section{Metode}

Metode penulisan yang kami gunakan untuk membuat jurnal ini adalah dengan menggunakan metode kualitatif deskriptif dengan studi literature review karena disini penulis 
mengambil melalui sumber dari jurnal, buku, dan juga ebook yang seseuai dengan materi yang sedangpenulisbahasdalamjurnalini, metode yang penulis gunakan ini yakni dengan membaca serta menganalisis terlebih dahulu sumber-sumber yang kami dapatkan sebelum kami review dan kami kutip untuk dijadikan sumber referensi bagi jurnal ini, tentunya sumber yang kami peroleh menggunakan bahasa yang jelas dan mudah dimengerti, setelah sumber dan data sudah penulis dapatkan maka selanjutnya akan diolah dan disusun kemudian dianalisis lalu disusun secara sistematis mengikuti pola yang semestinya sesuai dengan peraturan yang telah ditetapkan agar mempermudah bagi siapa saja yang membaca, menganalisa, maupun memahami.

\section{Hasil dan Diskusi}

Banyak sekali kejadian-kejadian atau fenomena tentang seseorang yang memilki perasaan enggan memaafkan keasalahan orang lain dan karena hal tersebut emosi negative yang terpendam sangat berpengaruh kepada hidup individu tersebut, bahkan sangat berdampak pada kesehtan mental seseorang. Salah satu contoh studi kasus yang berhubungan dengan orang yang tidak mau memaafkan. terjadi pada seorang anak. Anak ini masih tergolong dalam usia remaja, ia masih berusia 16 tahun. ia memilki obsesi untuk membunuh ayahnya, dikarenakan ia memiliki trauma di masa lalu. Dahulu ia sering melihat ayahnya melakukan tindak kekerasan terhadap anggota keluarganya, selain itu ia juga sering mendapat ancaman dari kakaknya, ancaman tersbut bukan hanya ancaman verbal saja tetapi juga kekerasan yang dilakukan kakaknya terhadap dirinya. Semua kekarasan yang pernah ia dapat di atau ia lihat di masa lalu membuat dirinya menyimpan perasaan marah, kecewa, sedih dan trauma, dan emosi negatif tersbutlah yang memnumbuhkan obsesi untuk dirinya agar dapat membalas perlakuan ayahnya dan hal tersebut mendorong ia untuk melakukan aksi balas dendam terhadap ayahnya untuk mengembalikan semua pelakuan ayahnya yang dulu ia terima, dengan cara mambunuh ayahnya. (Arifal)

Selain menimbulkan stress dan frustasi perasaan marah dan benci dapat menimbulkan keinginan untuk bunuh diri. Berikut merupakan salah satu contoh atudi kasus percobaan bunuh diri terjadi pada seorang wanita berinisial YS, ia merupakan seorang wanita yang berusia 36 tahun, ia belum menikah, ia merupakan seorang tunawisma. Sebelumnya ia telah dititipkan oleh kakaknya sendiri di Liponsos, sebelum dititipkan ia dan kakaknya sedang bertengkar, dan ternyata hubungan keduanya memeng tidak terlalu baik, ia merasa sudah tidak ada lagi keluarga yang peduli padanya. Pada saat di Liponsos ia sudah pernah malakukan percobaan bunuh diri, dan juga menyikiti dirinya sendiri. Keinginan untuk mengakhiri hidup berawal dari ia ternyat juga memliki dendam terhadap ayahnya yang dahulu sering melakukan tindak kekerasan kepada ibunya dan juga kakaknya yang juga sering memarah dirinya hingga memukul dirinya. Dan yang paling utama yang sering menjadi penyebab ia memiliki pikiran untuk bunuh diri adalah saat ia memgingat kakaknya, ia menjadi ingin membunuh kakaknya dan juga dirinya sendiri. Secara tidak sadak sadar YS sudah memendam dendam terhadap kakaknya. (Astrini \& Herdiana, 2018)

Selain itu perasaan marah dan kecewa yang berlebbihan ini juga dapat menimbulkan dampak untuk kesehatan mental seperti merasakan kecemasan. Contohnya seperti yang dirasakan oleh RA, ia mengalami suatu pelescahan seksual yang dilakukan oleh pamannya sendiri yaitu saudara dari ayahnya, kejadian itu terjadi pada saat ia sedang mandi di tempat pemanidan umum, ia mengalami pelecehan sesksual berupa visual. Hal tersebut membuat marah dan juga sedih, hal 
ini berakibat kepada kesehtan mental dirinya karen ia menjadi takut untuk bertemu kembali dengan pamannya. (Yudha \& Tobing, 2017)

Berikutnya juga terdapat studi kasus yang kurang lebih sama dengan stud kasus sebelumnya, kasus terjadi kepada seorang pendeta perempuan, ia sudah menjadi pendeta selama 16 tahun lamanya. Tak disangka ia memilki pengalaman buruk, ia pernah mengalami tindakan pelecehan sksual yang dilakukan oleh saudaranya sendiri. Pada saat itu ia masih duduk dibangku SD lebih tepatnya kelas 5 SD, kejadian tersebut terjadi di kamarnya karena memang pada saat itu sang pelaku sedang menginap di rumahnya. Semenjak kejadian tersebut ia merasa marah, sedih, kecewa bahkan sempat merasa jijik terhadap dirinya sendiri, bahkan ia juga merasa benci dan dendam kepada sang pelaku yang tak bisa ia lampiaskan. karena kejadian tersebut membuatnya mengalami setress berat dan membuatnya menjadi merasa rendah diri, menjadi pribadi yang pemalu. Juga karena emosi negative yang terpendam membuatnya enggan untuk menceritakan kepada siapapun yang berhubungan dengan hal tersebut. (Aprilia, 2021)

Dan terakhir terdapat kasus mengenai tawuran antar masyarakat desa Payowo dengan masyarakat Kelurahan Mangondow, aksi balas dendam ini bermula dari salah satu warga desa Payowo yang ditikam oleh salah satu warga dari keluarahan Magondow, dan dari kejadian tersebut terajdialah aksi tawuran antar warga, yang mneybabkan banyak warga yang mengalami luka-luka hingga ada yang meninggal dunia. (Bambuena, 2017)

Begitu banyak dampak negative yang terjadi jika seseorang enggan untuk kesalahan orang lain tau menyimpan dendam terhadap orang lain, seperti yang tertera pada beberapa studi kasus diatas, ada yang memilki obsesi untuk membalas dendam hingga membunuh pelaku, keinginan untuk bunuh diri karena menyimpan amarah terlalu lama, mengalami kecemasan dan perasaan ketakutan yang berlebihan jika melihat pelaku, perasaan benci, marah, kecewa yang teroendam terlalu lama, juga dapat menimbulkan stress, rasa sedih secara terus menerus, frsutasi, bahkan hingga obsesei untuk membalaskan dendam, dan dampak menyimpan dendam bukan hanya terjadi dalam mental seseorang melinkan juga rusaknya keharmonisan antar masyarakat karena aksi balas dendam.

Memaafkan atau forgiveness merupakan salah satu konsep dari pikologi positif. Dalam hubungan setiap individu tidak mungkin berjalan selalu baik, pasti selalu ada kesalah atau kesalah pahaman antar individu yang menimbulkan afektif negative dari setiap individu. Memaafkan merupakan pusat untuk mengembangkan manusia yang sehat dan hal yang paling penting adalah pemulihan hubungan interpersonal anatar individu setelah terjadinya konflik. Memaafkan juga dapat mengurangi tanggapan negative yang terjadi setelah konflik. Wothington menyatakan bahwa memaafkan berfungsi untuk mengurangi dan membatasi rasa benci dan dendam yang bersarang dalam hati individu yang memungkinkan mengacu pada pembalasan. Dalam bentuk sederhananya meaafkan dapat mengarahkan individu untuk merasakan suatu kebaikan dari pelaku, dengan kata lain memaafkan juga akan mengarahkan individu pada perasaan positif.

Nashori (2007), mendefinisikan pemaaf atau memaafkan merupakan suatu hal untuk menghapus luka atau bekas luka yang bersarang di dalam hati setiap individu. Pemaaf secara dewasa bukan berarti mengahpus semua luka atau perasaan negative yang bersarang, tetapi menjadi suatu keseimbangan perasaan. Keinginan untuk melakukan bukan berarti mengahapus semua perasaan yang negative yang pernah ada. Hal ini dapat dicapai oleh setiap individu asalakan 
setiap individu dapat mampu belajar dan belajar bahwa setiap individu memiliki kekurangan.(Warnaningrum, 2016)

Menurut Enright and Fitzgibbons's (2000) memaafkan memilki empat fase atau tahapan yaitu: 1) Fase pembukaan (uncovering). Fase ini adalah konfrontasi atau perlawanan terhadap rasa sakit emosional yang dialami oleh individu yang disebabkan oleh peristiwa yang menyakitkantersebut; 2) Fase pengambilan keputusan. Dalam fase ini korban mulai menyadari bahwa pengambilan keputusan untuk memamafkan akan menguntungkan atau akan berdampak baik bagi dirinya sendiri; 3) Fase tindakan. Pada fase ini pembentukan pola berfikir yang baru (reframing) akan dapat memfasilitasi perpective taking, empati dan rasa iba seseorang, dan 4) Fase hasil. Pada fase ini korban akan merasakan kelegaan emosional yang ada pada dirinya dan dapat meningkatkan rasa iba terhadap.

Dari beberapa fase yang telah diuraikan di atas dapat kita temukan kesimpulan bahwa yang paling utama dalam proses memaafkan adalah mengkonfrontasi emosi yang berhubungan dengan pengalaman atau peristiwa yang menyakitkan dan dapat menyelesaikannya, bahkan dapat melepaskan emosi negative yang tadinya bersarang pada diri individu terhadap orang yang menyakiti atau pelaku dan dapat menggantikan emosi negative tersebut menjadi emosi positif. (Kurniati, 2018)

Agama Islam selalu mengajarkan kepada setiap manusia untuk saling memaafkan satu sama lain. Sikap saling memaafkan adalah suatu wujud untuk saling menghormati sesama manusia, dan juga menjaga kehormatan, harta, serta martabat manusia. Sehingga tali silahturahmi antara manusia tetap terjaga. Dalam surat Asy-syuura ayat 40 yang Artinya "Dan balasan suatu kejahatan adalah kejahatan yang serupa, maka Barang siapa memaafkan dan berbuat baik maka pahalanya atas (tanggungan) Allah. Sesungguhnya Dia tidak menyukai orang orang yang lain”. Dalam surat ini dijelaskan bagi orang yang memaafkan kesalahan orang lain dan tetap menjalin silahturahmi dan hubungan baik dengan orang lain, orang tersebut akan mendapatkan pahala dari Allah SWT.(Widyawati, 2017)

Memaafkan kesalahan orang termasuk hal yang menguntungkan bagi seseorang, kerana dengan memaafkan kita tidak perlu lagi memikirkan kesalahan orang lain, yang itu juga dapat menyakiti diri kitas endiri. Kita akan merasakan kelegaan. (Listywati, 2016). Martin Saligman merupakan ketua dari Positive Pshychology Center yang terdapat di University of Pennsylvania. Ia mendefinisikan psikologi positif merupakan "kajian ilmiah mengenai kekutan dan kebajikan yang memungkinkan individu-individu dan komunitas-komunitas untuk berkembang dengan cepat”. Riset ini terfokus kepada emosi-emosi positif yang dimliki oleh setiap individu

Psikologi positif melihat bagaimana cara individu memanfaatkan kekutan yang dimilki oleh setiap individu untuk mengjar tugas-tugas menantang yang akan membawa individu kepada pengalaman yang kemudian akan membawa kepada kehidupan yang penuh makna, yaitu kebahagiaan yang sejati. (Kelly, 2008). Psikologi positif memiliki tujuan untuk mengaktulisasikan suatu perubahan positif yang ada pada diri setiap individu, tidak hanya memeperbaiki sesuatu yang buruk, tetapi juga mengembangkan kualitas yang ada pada diri setiap individu dan memperbaiki yang tidak seimbang pada waktu lalu. 
Sedangkan psikologi memiki tujuan yang paling utama yaitu, menawarkan keseimbangan korektif dengan psikologi tradisional, dan tetap mempertahankan hasil akhir dari berbagai rangakaian yang lebih kearah positif. Psikologi positif ini muncul untuk lebih menekankan terhadap pentingnya untuk dapat mempelajari atau melihat perilaku dari setiap individu melalui sisi positif individu tersebut. Contohnya seperti emosi positif, motivasi, dan menjalankan hubungan yang positif dengan orang lain.(Moesaeofah, 2021). Dalam psikologi positif ini individu harus mampu menerapkan sikap optimisme, ketahanan, keberanian, kekuatan, kebahagiaan, dll. Siapa saja yang mampu menerapkan sikap-sikap diatas akan mudah menerapkan konsep psikologi positif.(Manurung, 2017).

Para ahli psikologi menyatakan bahwa kehidupan seseorang akan lebih bermakna dan berbahagia jika seseorang tersebut dapat mengembangkan sisi positif mereka dengan maksimal. Sisi positif tersebut adalah emosi positif dan kepribadian yang bijaksana dan pandai bersyukur dan juga memaafkan. Emosi yang positif terdiri dari kebahagiaan, besyukurdenganapa yang dimiliki, dan juga memaafkankejadianataukesalayang yang pernah terjadi. Kepribadian sifat positif yang dirancang ahli psikologi positif seperti rasa ingin tahu, kreatif, keberanian, pikiran masa depan, optimisme, setia, etika kerja yang baik, akrab, kejujuran, baik hati, semangat, kepedulian, keadilan, ketekunan dan memiliki kapasitas untuk mengalir dan mencerahkan.(Yudhawati, 2018)

Psikologi mempunyai atau memilki tiga pilar atau pondasi yang cukup kuat atau yang paling utama, yaitu yang pertama adalah pengalaman hidup yang positif bagi setiap individu atau manusia dan dapat lebih mengeksplorasi emosi-emosi positif yang ada dalam diri individu. Pondasi yang kedua adalah property fisik yang positif dari setiap individu, dapat menggali trait kepribadian yang positif, semisal seperti bakat dan kekuatan yang ada dalam diri setiap individu. Dan yang terakhir atau yang ketiga adalah lingkungan sosial masyarakat yang positif, menggali suatu hubungan sosial yang positif, contohnya seperti demokrasi, keluarga yang harmonis dan pendidikan yang dapat mendukung setiap perkembangan positif yang ada dalam diri individu (Aulia, 2021). Spiritualitas dalam psikologi positif juga sangat berpengaruh dan berperan penting dalam konsep psikologi positif seseorang karena spiritualitas menghubungkan kehidupan seluruh kehidupan manusia dialam dunia dengan alam akhirat jadi keduanya saling berkaitan dan harus seimbang antara keduanya untuk konsep psikologi yang baik. (Wiguna, 2017).

Menurut Seligman (2005) terdapat dua faktor yang berpengaruh dalam kebahagiaan seseorang, yaitu terdapat faktor eksternal dan faktor internal. Faktor eksternal yaitu faktor yang berasal dari luar atau lingkungan seseorang seperti, uang, emosi positif, pernikahan, kehidupan sosial, usia, agama kesehatan dan lainnya. Sedangkan faktor internal itu beasal dari dalam seseorang itu sendiri, seperti kepuasan terhadap masa lalu, optimism terhadap masa depan, dan kebahagiaan untuk masa sekarang. Untuk kepuasan terhadap masa lalu, memaafkan merupak salah satu hal yang dapat menumbuhkan kepuasan tersebut.(Rienneke \& Setianingrum, 2018).

Memaafkan sering dikaitkan dengan dua hal yaitu meminta maaf dan memaafkan. Menurut Horwitz (2005), ia merupakan seorang ahli Psikoanalitik dari Greator Kansas City Pshycoanalitik Institute, untuk melakukann duahal tersebut memerlukan beberapa hal yang terlibat di dalamnya, seperti, korban, pelaku dan berbagaitingkatan trauma dan luka. Sedangkan menurut Soesilo (2006), memaafkan merupakan proses penyembuhan dari ingatan yang terluka , bukan untuk mengahapus. Menurut beberapa ahli memaafkan juga diartikan sebagai cara pemulihan hubungan 
yang rusak secara pro -sosial. Mc Cullough dan teman-temanya menambahkan fungsi dalam hal memaafkan, yaitu "sistem pemaafan" yang dapat mengahasilkan perubahan motivasi karena keberhasilan individu untuk mendoorong adanya penyembuhan hubungan yang akan menguntungkan untuk mengurangi akibat yang dapat merugikan interpersonal.

Memaafkan bisa sama diartikan sebagai balas dendam, masing-masing individu baik pelaku ataupun korban pasiti mengalami efeknya masing-masing. Memafakan dalam sisi korban dapat menghasilkan untuk mempersiapkan diri memasuki hubungan yang baik dengan pelaku berdasarkan dengan prospek menangkap manfaat melalui hubungan tersebut. Memaafakan juga memiliki fungsi untuk mengurangi perasaan balas dendam. Worthington, Hook, Utsey, Williamd dan Neil (2007), lebih menekankan keputusan untuk memaafkan dalam aspek emosi, yaitu ketika seseorang merasa tersakiti dan terluka dan memutuskan untuk memaafkan sang pelaku, berarti dia memutuskan untuk tidak membalas dendam atau berusaha untuk menghindari haltersebut. Dia akan berusaha untuk melakukan rekonsiliasi.(Warsah, 2021)

Kesehatan mental merupakan suatu keadaan dimana seseorang atau individu atau kelompok masyarakat lengkap secara fisik, mental dan kesejahteraan sosial yang dimana mereka merasakan adanya keharmonisan antara fisik dan mental sehingga mereka mudah melakukan suatu kegiatan aktivitas tanpa adanya hambatan apapun. Menurut World Health Organization (WHO) mendefinisikan bahwa kesehatan mental itu adalah kondisi kesejahteraan individu yang menyadari potensinya sendiri, yang dapat mengatasi masalah-masalahkehidupan yang menimpanya, yang mana individu tersebut dapat bekerja apapun dan dapat menghasilkan guna memenuhi kehidupannya, dan mampu berperan atau berkontribusi pada lingkungannya dalam artian ikut serta turut aktif dalam kehidupan bermasyarakat.(Fakhriyani, 2015)

Kesehatan mental merupakan suatu keadaan yang berhubungan dengan psikologi seseorang yang mempengaruhi pikirannya, kejiwaan dan perilakunya di masyarakat, dimana tidak ada gejala gangguan mental dan dapat menjalankan hidup dengan baik. Perilaku yang dimaksud disini adalah bagaimana cara mereka bersosialisasi dan berkomunikasi dengan baik kepada masyarakat sesuai dengan norma yang telah ditetapkan. Menurut Undang-Undang RI Tahun 2014 Pasal 1 menyatakan bahwa kesehatan mental merupakan kondisi seseorang yang berkembang secara fisik, mental, spiritual dan sosial sehingga dapat mengatasi permasalahan dalam hidupnya dan mampu bekerja dengan layak untuk memenuhi kehidupannya.(Saputra \& Tulus, 2018).

Kesehatan mental adalah terhindarnyaseseorangdarigangguan mental baik psikosis maupun neurosis, seseorang sehat mental akan mudah menyesuaikan diri terhadap lingkungannya, orang yang sehat mental juga akan senantiasa merasa aman dan bahagia dalam kondisi apapun, dan orang sehat mental akan bekerja untuk memenuhi kebutuhan hidupnya. Kesehatan mental bagi manusia tidak bisa terlepas dari yang namanya Agama, seberapa jatuh manusia akan kembali ke agamanya, dan pada hakikatnya manusia adalah mahluk yang bertuhan termasukk etika mengalami sakit mental maka seseorang akan memohon kepada tuhan-Nya sebagaimana AlQuran sebagai As-Syifa (obat).

Gangguan kesehatan mental dapat dikatakan sebagai perilaku abnormal atau perilaku menyimpang dari norma yang ada di masyarakat, perilaku yang ditampakanbisaberupastres, depresi, dll. Sehingga dapat disimpulkan bahwa gangguan kesehatan mental terdapat satu titik kunci yakni menurunnya fungsi mental yang berpengaruh pada ketidak wajaran berperilaku 
seseorang. Gangguan mental juga disebutkan dalam Al-Quran Surah Al-Baqarah ayat 10 yang artinya "Dalam hati mereka ada penyakit lalu ditambah Allah penyakitnya, dan bagi mereka sisksa yang pedih disebabkan mereka berdusta.". Maka dari itu telah dijelaskan juga bahwa agama sebagai terapi kesehatan mental seperti dalam (QS.An-Nahl: 97) "Barang siapa mengerjakan amal saleb baik laki-laki maupun perempuan dalam keadaan beriman, Maka sesunggubnya Allah akan berikan kepadanya kebidupan yang baik dan sesungguhnya akan kami berikan balasan kepada mereka dengan pahala yang lebih baik dari apa yang telah mereka kerjakan". (Ariadi, 2016)

Enright (2001) berkata memaafkan akan mempengaruhi kesehatan mental melalui empat tahapan, tahap pertama yaitu mengungkapkan atau membuka yang merupakan tahap fundamental dalam proses memaafkan. Kedua adalah tahap memutuskan yaitu seseorang telah mencapai pemahaman yang benar tentang pemaafan yang sesungguhnya dan membuat keputusan untuk berkomitmen. Ketiga yaitu bertindak atau bekerja yang mana seseorang telah mencapai sebuah pemahaman kognitif terhadap orang yang telah melukai dirinya dan mulai memandang dengan perspektif baru. Keempat yaitu pendalaman dimana seseorang menemukan peningkatan makna dalam penderitaan, merasa lebih terhubung dengan orang lain dan pada saat bersamaan tumbuh untuk memperbaharui hidupnya.

Kemampuan seseorang untuk bisa memaafkan secara tulus, dapat terlepas dari penderitaannya atau emosi negatiif yang selama ini ia rasakan dan menggantinya dengan emosi positif. dan dapat menemukan tujuan baru dalam hidupnya. Dalam memaafkan terdapat proses yang berfungsi untuk mengembangkan kesejahteraan psikologis, yang dapat menjadi aspek penting untuk individu yang sehat mental.(Aziz, Nurwahyuni, \& Wargadinata, 2017). Memaafkan merupkan suatu aspek penting untuk membentuk kesehtan mental seseorang. Memaafkan memilki fungsi yang baik yaitu sebagai penangkal stress, penangkal permusuhan dan juga penengakal penurunan kesehatan. Fungsi memaafakan lainnya adalah untuk mengembangakan emosi positif lainnya yang berhubungan dengan kesehatan mental. Untuk menumbuhkan kesehatan mental yang baik maka motovasi untuk berbaik hati dan memaafkan orang yang telah berbuat kesalahan memiliki peran yang besar dalam menumbuhakan kesehtan mental yang baik.(Rahmah, 2017).

Melalui penjabaran yang terdapat di atas, memaafkan sangtlah penting dalam kesehatan mental seseorang, bahkan bukan hanya kesehatan mental tetapi juga dengan kesehatan fisik. Seseorang yang sudah dapat memaafkan dengan ikhlas berarti mereka sudah melepaskan perasaan benci yang ada di dalam diri mereka, dengan memaafkan seseorang akan merasakan kelegaan karena mereka sudah bisa melepaskan apa yang menjadi beban di dalam hati mereka.

Memendam kebencian sangatlah tidak baik bagi kesehatan mental maupun fisik, karena, dengan kita menyimpan kebencian kepada seseorang, kita akan terus mengingat hal yang menyakiti perasaan kita seperti kaset rusak yang hanya berulang-ulang, semakin diingat akan tersakiti kembali. Dan kembali akan mengganggu kesehatan mental individu tersebut, jika kesehatan mental sudah terngganggu maka tidak menutup kemungkinan jika kesehtan fisik juga akan terganggu. Untuk urgensi memaafkan dalam kesehatan mental, adalah semakin individu bisa menghilangkan rasa dendam, rasa marah dan benci maka dengan memaafkan akan mampu meningkatkan kesehatan mental yang baik bagi individu tersebut, sebaliknya semakin individu itu selalu memikirkan kesalahan orang lain, selalu memikirkan cara untuk mempermalukan seseorang 
maka kesehatan mental bagi orang tersebut akan semakin buruk karena sudah dikuasai oleh nafsu yang jahat. Maka dari itusangatlah penting memaafkan dengan sehat mental karena hal itu berkaitan cukup dekat.

\section{Kesimpulan}

Kesehatan mental adalah kondisi kesejahteraan individu yang menyadari potensinya sendiri, yang dapat mengatasi masalah-masalah kehidupan yang menimpanya, yang mana individu tersebut dapat bekerja apapun dan dapat menghasilkan guna memenuhi kehidupannya, dan mampu berperan atau berkontribusi pada lingkungannya dalam artian ikutserta turut aktif dalam kehidupan bermasyarakat. Namun kesehatan mental seseorang biasanya ada yang terganggu dengan penyebab karena faktor somatogenik, neroanatomi, dan nerofisiologi, dengan penyebab tersebut maka banyak sekali upaya untuk mengatasi masalah kesehatan mental tersebut salah satunya adalah pendekatan preventif, kuratif dan multisektoral. Selanjutnya psikologi positif yang berperan untuk melihat bagaimana cara individu memanfaatkan kekutan yang dimilki oleh setiap individu untuk mengjar tugas-tugas menantang yang akan membawa individu kepada pengalaman yang kemuduan akan membawa kepada kehidupan yang penuh makna, yaitu kebahagiaan yang sejati. Untuk mencapai kebahagiaan sejati maka diperlukan ada sikap memaafkan dari diri seseorang yang mana hal itu sangat penting dan berpengaruh sekali terhadap kesehatan mental seseorang.

\section{Ucapan Terima Kasih}

Terimakasih kepada Allah SWT yang telah memberikan umur panjang, kesehatan, dan kelancaran atas semua nya, dan juga terimakasih telah diberikan kemudahan dalam mengatasi kesulitan yang dihadapi. Terimakasih kepada semua rekan-rekan yang telah membantu, terimakasih kepada penulis telah menyusun jurnal ini dengan baik dan benar sesuai aturan, terimakasih kepada orang tua telah menyediakan alat-alat seperti laptop, handphone, dll yang sangat bermanfaat sekali dalam penyusunan jurnal ini hingga selesai. Terimakasih juga kepada sumber-sumber buku, jurnal, skripsi, ebook, yang telah memberikan cukup banyak referensi bahan bacaan yang membantu penyusunan jurnal ini.

\section{Referensi}

Alifah, A. M., Prihartanti, N., \& Rosyidi, I. (2016). Dinamika Psikologis Narapidana Anak Pelaku Pembunuhan: Studi Kasus Di Lapas Anak Kutoarjo. Indigenous: Jurnal Ilmiah Psikologi, 13(2).

Aprilia, P. D., Ranimpi, Y. Y., \& Yonathan, H. (2021). Tinjauan Psiko-Teologis Terhadap Pengalaman Traumatik Seksual dan Panggilan Menjadi Pendeta. GEMA TEOLOGIKA: Jurnal Teologi Kontekstual dan Filsafat Keilabian, 6(2), 265-278.

Ariadi, P. (2019). Kesehatan Mental dalam Perspektif Islam. Syifa'MEDIKA: Jurnal Kedokteran dan Kesehatan, 3(2), 118-127.

Astrini, R. A., \& Herdiana, I. (2020). Gambaran Risiko Bunuh Diri pada Wanita Tunawisma di Pondok Sosial Surabaya: Studi Kasus. Psikologia: Jurnal Psikologi, 3(1), 1-10. 
Aulia, F. (2015). Aplikasi Psikologi Positif Dalam Konteks Sekolah. In Seminar Psikologi \& Kemanusiaan (p. 121).

Ayuningtyas, D., \& Rayhani, M. (2018). Analisis situasi kesehatan mental pada masyarakat di Indonesia dan strategi penanggulangannya. Jurnal Ilmu Kesehatan Masyarakat, 9(1), 1-10.

Aziz, R., Wahyuni, E. N., \& Wargadinata, W. (2017). Kontribusi bersyukur dan memaafkan dalam mengembangkan kesehatan mental di tempat kerja. INSAN Jurnal Psikologi Dan Kesehatan Mental, 2(1), 33-43.

Bambuena, M. P., Nayoan, H., \& Egeten, M. (2017). Koordinasi Pemerintah Kecamatan dalam Mencegah Tawuran Antar Kampung (Studi Kasus Kelurahan Mongondow dan Desa Poyowa Kecil, Kecamatan Kotamobagu Selatan, Kota Kotamobagu). Jurnal Eksekutif, 1(1).

Burhanuddin, B. (2020). Zikir Dan Ketenangan Jiwa (Solusi Islam Mengatasi Kegelisahan dan Kegalauan Jiwa). Jurnal Mimbar: Media Intelektual Muslim dan Bimbingan Rohani, 6(1), 1-25.

Detik.com. (2015). "suka menyimpan dendam pada orang lain bias berdampak buruk bagi kesehatan". Retrieved From https://health.detik.com/berita-detikhealth/d-2695498/sukamenyimpan-dendam-pada-orang-lain-bisa-berdampak-buruk-bagi-kesehatan

Fakhriyani, D. V. (2019). Kesehatan Mental (Vol. 124). Duta Media Publishing.

Ibrahim, S. (2020). Berdakwah Dengan Hati. Jakarta : Pustaka Al-Kautsar

Kallang, A. (2020). Teori untuk Memperoleh Ketenangan Hati. Al-Din: Jurnal Dakwah dan Sosial Keagamaan, 6(1).

Kelly, K. (2018). The Secret of The Secret. Bandung: Penerbit Mizan.

Listywati, R. (2018). Kepak Sayap Patab: Tumbangkan Sedibmu, Terbangkan Bahagiamu. (2018). (n.p.): Anak Hebat Indonesia.

Manurung, R. T. (2010). Kajian Maksim: Perilaku Tindak Tutur dengan Pendekatan Psikologi Positif. Jurnal Sosioteknologi, 9(19), 812-824.

Moesarofah, M. (2021, September). Kecemasan Pembelajaran Jarak Jauh Ditinjau dari Pendekatan Psikologi Positif. In Seminar Nasional Psikologi UM (Vol. 1, No. 1, pp. 165-171).

Nasri, S. A., Nisa, H., \& Karjuniwati, K. (2018). Bagaimana Remaja Memaafkan Perceraian Orang Tuanya: Sebuah Studi Fenomenologis. Seurune: Jurnal Psikologi UNSYLAH, 1(2), 102-120.

Rahmah, H. (2018). Penerapan Aspek Kesejahteraan Psikologis dan Pemaafan Dalam Membentuk Kesehatan Mental. Al Qalam: Jurnal Ilmiah Keagamaan dan Kemasyarakatan.

Rienneke, T. C., \& Setianingrum, M. E. (2018). Hubungan antara forgiveness dengan kebahagiaan pada remaja yang tinggal di Panti Asuhan. Persona: Jurnal Psikologi Indonesia, 7(1), 18-31.

Saputra, F. A., Ranimpi, Y. Y., \& Pilakoannu, R. T. (2018). Kesehatan Mental dan Koping Strategi di Kudangan, Kecamatan Delang, Kabupaten Lamandau Kalimantan Tengah: Suatu Studi Sosiodemograf. Humanitas (Jurnal Psikologi), 2(1), 63-74.

Warnaningrum, I. D. (2016). Perilaku Memaafkan Pada Korban Bullying Fisik di SMP Gunung Jati 2 Purwokerto Tabun Ajaran 2015/2016 (Skripsi, Universitas Muhammadiyah Purwokerto).

Warningrum,I,D, (2016), Perilaku Memaafkan Pada Korban Bullying Fisik di SMP Gunung Jati 2 PurwokertoTabunAjaran 2015/2016, bttp:/ / repository.ump.ac.id/2903/3/Intan\%20Desy\%20W arnaningrum BAB\%20II.pdf

Warsah, I. (2021). Pendidik Inspiratif. Sleman: Deepublish. 
Widiyawati, N. (2017). Konsep maaf perspektif al-Qur'an (Studi tafsir Tematik) (Skripsi, IAIN Ponorogo).

Wiguna, A. (2017). Upaya mengembangkan sikap spiritual dan sosial peserta didik berbasis psikologi positif di sekolah. AL-AS ASIYYA: Journal Of Basic Education, 1(2).

Yudha, I. N. B. D., \& Tobing, D. H. (2017). Dinamika Memaafkan Pada Korban Pelecehan Seksual. Jurnal Psikologi Udayana, 4(2), 435-447.

Yudhawati, D. (2018). Implementasi Psikologi Positif Dalam Pengembangan Kepribadian Mahasiswa. Psycho Idea, 16(2), 111-118. 